\title{
Analisis Perubahan Kerapatan Vegetasi dan Bangunan di Kota Banda Aceh Pasca Bencana Tsunami
}

\section{Analysis of Vegetation and Building Density Changes in the Banda Aceh City Post-Tsunami Disaster}

\author{
Rahmat Nanda Trinufi ${ }^{\mathrm{a}}$, Sri Rahayu ${ }^{\mathrm{b}} *$ \\ ${ }^{a}$ Departemen Perencanaan Wilayah dan Kota Universitas Diponegoro, Semarang, Indonesia \\ ${ }^{b}$ Departemen Perencanaan Wilayah dan Kota Universitas Diponegoro, Semarang, Indonesia
}

\begin{abstract}
Abstrak
Pesatnya pembangunan di suatu kota akan berdampak pada kerapatan bangunan yang semakin tinggi dan menyebabkan kerapatan vegetasi terus berkurang. Kota Banda Aceh pasca bencana tsunami mengalami perkembangan yang cukup pesat terutama pada perubahan lahan. Perubahan lahan tersebut tentunya akan berpengaruh terhadap perubahan kerapatan vegetasi dan bangunan. Tujuan penelitian ini untuk mengkaji perubahan kerapatan vegetasi dan bangunan di Kota Banda Aceh pasca bencana tsunami. Penelitian ini menggunakan pendekatan kuantitatif dengan data citra landsat (2005 dan 2011) dan citra sentinel (2019) dan menggunakan software QGIS dengan metode NDVI untuk mengetahui perubahan kerapatan vegetasi dan NDBI untuk mengetahui perubahan kerapatan bangunan. Berdasarkan hasil penelitian diketahui telah terjadi perubahan kerapatan di Kota Banda Aceh. Perubahan paling signifikan terjadi pada periode 20052011, perubahan kerapatan vegetasi paling besar terjadi pada kelas cukup rapat sebesar 10,81\% (647.55 Ha). Sedangkan perubahan kerapatan bangunan paling besar terjadi pada kelas kerapatan rendah sebesar 9,53\% (571,06 Ha). Sementara itu, pada periode 2011-2019 perubahan kerapatan vegetasi paling besar terjadi pada kelas vegetasi jarang yaitu sebesar 10,08\% (603.80 Ha). Sedangkan pada kerapatan bangunan, kelas yang mengalami perubahan paling besar terjadi pada kelas kerapatan sangat tinggi sebesar 2,53\% (168,19 Ha). Perubahan kerapatan vegetasi dan bangunan cenderung terjadi di daerah pinggiran Kota Banda Aceh.
\end{abstract}

Kata kunci: Kerapatan Vegetasi, Kerapatan Bangunan, Penginderaan Jauh

\begin{abstract}
The rapid urban growth will have an impact on the higher building density and cause the density of vegetation to continue to decrease. Banda Aceh developed so rapidly especially on land changes after tsunami. Land conversion will certainly affect in vegetation and building densities. The purpose of this study is to analyze vegetation and building densities conversion in Banda Aceh After Tsunami. This research uses a quantitative approach with Landsat imagery (2005 and 2011) and sentinel imagery (2019) and software QGIS with NDVI methods to determine conversion in vegetation density and NDBI to determine conversion in building density. Based on research, there has been a conversion term of density in Banda Aceh. The most significant conversion occurred in between 2005-2011, the largest conversion in vegetation density occurred in the fairly dense class of $10.81 \%(647.55 \mathrm{Ha})$. Whereas on conversion in building density, the low density class increase of 9.53\% (571,06 Ha). Meanwhile, in the 2011-2019 the greatest conversion in vegetation density occurred in the sparse vegetation class of $10.08 \%(603.80 \mathrm{Ha})$. Meanwhile in building density, the class that have the greatest growth occurred in the very high density class of $14.38 \%$. Conversion in vegetation and building densities tended to occur in the suburbs of Banda Aceh.
\end{abstract}

Keyword: Vegetation Density, Building Density, Remote Sensing.

\footnotetext{
* Corresponding author. Rahmat Nanda Trinufi

E-mail address: rahmatnandatrinufi@gmail.com
} 


\section{Pendahuluan}

Pada dasarnya kota selalu mengalami perubahan. Perubahan kota biasanya dipengaruhi oleh beberapa faktor seperti sosial, budaya, politik, ekonomi dan fisik (Kurniawati, 2010). Perubahan tersebut membuat setiap kota terus mengalami perkembangan. Perkembangan kota merupakan proses perkembangan keadaan kota dari suatu keadaan ke keadaan lain yang terjadi dalam kurun waktu yang berbeda, perkembangan kota ini terjadi secara alami maupun atas campur tangan manusia. Perkembangan kota biasanya didorong oleh tingginya intensitas pertambahan jumlah penduduk yang menyebabkan aktivitas dan kebutuhan masyarakat meningkat. Hal ini biasanya menyebabkan kebutuhan akan lahan terbangun terus meningkat dan memicu terjadinya peningkatan pembangunan.

Pembangunan ini tentunya akan berdampak pada fisik lingkungan dan mengakibatkan terjadinya alih fungsi lahan dari lahan vegetasi menjadi lahan terbangun. Alih fungsi lahan yang terjadi akibat peningkatan pembangunan biasanya akan berdampak pada kerapatan bangunan yang semakin tinggi (Hardyanti et al., 2017). Semakin tinggi perubahan kerapatan bangunan yang terjadi maka akan berdampak pada kerapatan vegetasi yang terus mengalami penurunan (Aftriana et al., 2013). Fenomena ini tentunya berpengaruh kepada perubahan kerapatan vegetasi dan bangunan yang terjadi di Kota Banda Aceh.

Kota Banda Aceh merupakan kota yang mengalami perkembangan akibat bencana tsunami yang terjadi pada tahun 2004. Jumlah korban akibat bencana tsunami sebanyak sebanyak 61.262 jiwa atau mencapai $25,61 \%$ dari total jumlah penduduk pada saat itu. Disisi lain, dampak dari bencana tsunami juga mencakup pada aspek fisik dan non fisik baik seperti masalah kesehatan, psikologi, pendidikan dan penggunaan lahan Kota Banda Aceh. Pasca bencana tsunami, Kota Banda Aceh mengalami perkembangan yang cukup pesat terutama pada perubahan lahan. Perkembangan ini juga didukung oleh implementasi kebijakan pemerintah Kota Banda Aceh dalam upaya pembangunan kawasan yang berfokus pada rehabilitasi kota akibat dari bencana tsunami. Pesatnya pembangunan dan perkembangan kawasan yang terjadi di Kota Banda Aceh akan menyebabkan terjadinya perubahan lahan. Perubahan lahan tersebut tentunya akan berpengaruh pada perubahan kerapatan vegetasi dan bangunan yang terjadi di Kota Banda Aceh. Namun, sampai saat ini Kota Banda Aceh belum memiliki informasi terkait perubahan kerapatan vegetasi dan bangunan. Ada beberapa cara cepat untuk mengetahui perubahan kerapatan vegetasi dan bangunan di suatu wilayah. Salah satu caranya yaitu dengan menggunakan dan memanfaatkan data penginderaan jauh. Saat ini penginderaan jauh sering di pakai untuk menganalisis data spasial karena memiliki kelebihan lebih efektif dan efisien serta dapat lebih menghemat waktu dan biaya (Choudhary et al., 2018).

Penginderaan jauh merupakan alat yang efektif untuk melakukan pemetaan kerapatan vegetasi dan kerapatan bangunan karena memiliki kemampuan untuk mengumpulkan informasi pada suatu wilayah (Jia et al., 2014). Untuk mengetahui informasi terkait sebaran dan kerapatan bangunan dan vegetasi di suatu wilayah dapat dilakukan dengan metode perhitungan numerik sederhana yaitu Normalized Difference Build-Up Index (NDBI) dan Normalized Difference Vegetation Index (NDVI). NDBI dan NDVI merupakan metode yang melibatkan saluran/band dari data penginderaan jauh yang akan menghasilkan citra baru untuk menunjukkan tingkat kerapatan vegetasi dan bangunan di suatu daerah. Oleh karena itu, untuk mendapatkan gambaran terkait kerapatan vegetasi dan bangunan Kota Banda Aceh, maka perlu dilakukan kajian tentang perubahan kerapatan vegetasi dan bangunan dengan menggunakan data penginderaan jauh. Tujuan dari penelitian ini adalah untuk mengkaji perubahan kerapatan vegetasi dan bangunan di Kota Banda Aceh pasca bencana tsunami.

\section{Metode}

Metode penelitian yang digunakan dalam penelitian ini yaitu deskriptif kuantitatif. Data yang digunakan dalam penelitian ini didapat melalui dua sumber yaitu pengumpulan data primer dan pengumpulan dapat sekunder. Penelitian ini merupakan penelitian yang menghasilkan perubahan kerapatan vegetasi dan bangunan secara time series dari hasil pengolahan data penginderaan jauh landsat 5 TM (2005 dan 2011) dan sentinel 2 (2019). Data citra landsat 5 TM dan citra sentinel 2 didapat melalui website USGS (https://earthexplorer.usgs.gov/) dengan batasan lingkup path 131 dan row 56. Penggunaan data tahun 2005 untuk melihat kerapatan 
vegetasi dan bangunan Kota Banda Aceh yang terjadi akibat dari bencana tsunami pada tahun 2004. Data tahun 2019 digunakan untuk melihat perubahan kerapatan vegetasi dan bangunan saat ini dan data tahun 2011 merupakan transisi yang digunakan untuk melihat fenomena perubahan yang terjadi. Pengolahan data dalam penelitian ini dengan software QGIS menggunakan metode algoritma NDVI untuk mengetahui indeks kerapatan vegetasi dan algoritma NDBI untuk mengetahui indeks kerapatan bangunan.

- Indeks Kerapatan Vegetasi

Indeks kerapatan vegetasi yang didapat dari algoritma NDVI dapat dilakukan dengan cara sebagai berikut.

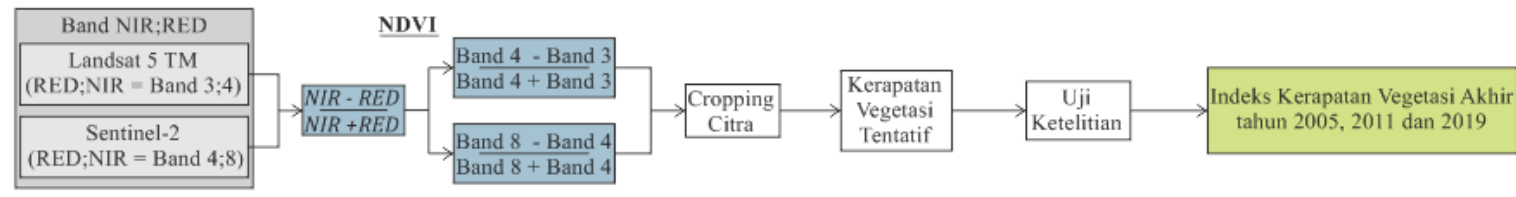

Gambar 1. Diagam pengolahan indeks kerapatan vegetasi (Analisis Penyusun, 2019)

Hasil dari pengolahan NDVI akan menunjukkan rentang nilai -1 dan +1 , semakin mendekati 1 maka nilai kerapatan vegetasi semakin sangat rapat (Gascon et al., 2016). Berdasarkan rentang nilai tersebut dapat dibuat klasifikasi kelas kerapatan vegetasi sebagai berikut.

Tabel 1. Indeks Kerapatan Vegetasi (Analisis Penyusun, 2019)

\begin{tabular}{cc}
\hline Klasifikasi Kerapatan & Indeks Kerapatan Vegetasi \\
\hline Sangat Rapat & $0,35-1$ \\
Rapat & $0,25-0,35$ \\
Sedang & $0,15-0,25$ \\
Jarang & $0-0,15$ \\
Non Vegetasi & $-1-0$ \\
\hline
\end{tabular}

- Indeks Kerapatan Bangunan

Indeks kerapatan bangunan yang didapat dari algoritma NDBI dapat dilakukan dengan cara sebagai berikut.

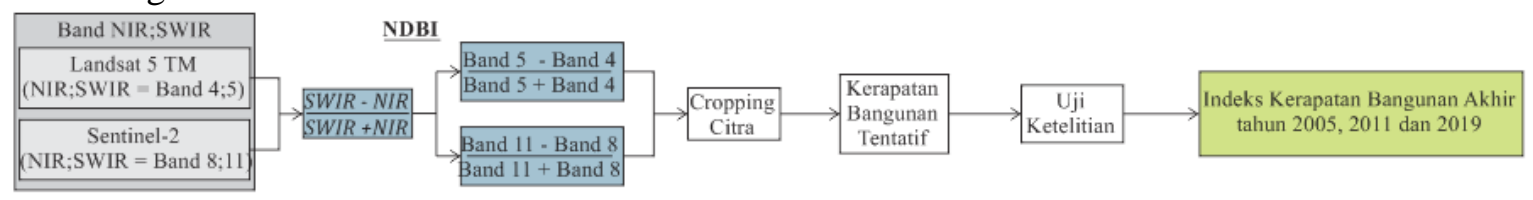

Gambar 2. Diagram pengolahan indeks kerapatan bangunan (Analisis Penyusun, 2019)

Hasil dari pengolahan NDBI akan menujukkan rentang nilai -1 dan +1 , dimana semakin mendekati nilai 1 maka tingkat kerapatannya semakin tinggi. Berdasarkan rentang nilai tersebut dapat dibuat klasifikasi kelas kerapatan bangunan sebagai berikut.

Tabel 2. Indeks Kerapatan Bangunan (Analisis Penyusun, 2019)

\begin{tabular}{cc}
\hline Klasifikasi Kerapatan & Indeks Kerapatan Bangunan \\
\hline Sangat Tinggi & $0,3-1$ \\
Tinggi & $0,2-0,3$ \\
Sedang & $0,1-0,2$ \\
Rendah & $0-0,1$ \\
Non Terbangun & $-1-0$ \\
\hline
\end{tabular}

- $\quad$ Uji Akurasi

Hasil dari pengolahan NDVI dan NDBI diperlukan uji ketelitian untuk melihat nilai akurasi dari klasifikasi. Untuk mengetahui nilai akurasi data hasil pengolahan dapat dilakukan dengan menggunakan confusion matrix atau matriks kesalahan. Confusion matrix adalah tabel yang sering digunakan untuk mengambarkan kinerja model klasifikasi pada data uji yang nilai sebenarnya diketahui. Penilaian paling sederhana untuk menghitung tingkat akurasi dari 
confusion matrix dilakukan dengan cara membandingkan antara total sampel benar dengan total sampel dalam matriks secara keseluruhan (Congalton, 1991). Jika dirincikan, maka uji akurasi dapat dilakukan dengan perhitungan sebagai berikut.

$$
\text { Overall Accuracy }=\frac{\text { Jumlah } \text { sampel benar }}{\text { Jumlah seluruh sampel }} \times 100 \%
$$

Hasil klasifikasi dikatakan baik apabila nilai keakuratan didapat $\geq 80 \%$ atau kesalahannya $\leq 20 \%$ dibandingkan dengan kondisi eksisting lapangan (Anderson et al., 1976).

\section{Kajian literatur}

\subsection{Perkembangan Kota}

perkembangan kota (Urband Development) dapat diartikan sebagai suatu perubahan menyeluruh, yaitu yang menyangkut segala perubahan di dalam masyarakat kota secara menyeluruh, baik perubahan sosial ekonomi, sosial budaya dan perubahan fisik (Hendarto, 1997). Sujarto (1990) menjelaskan pada umumnya perkembangan dan pertumbuhan kota di pengaruhi oleh tiga faktor utama yaitu faktor manusia, faktor kegiatan dan faktor pola pergerakan. Secara umum, perkembangan kota akan berbanding lurus dengan pertumbuhan penduduk, dimana setiap peningkatan penduduk akan mempengaruhi perkembangan perkotaan. Pertumbuhan penduduk tersebut mengakibatkan kebutuhan lahan semakin tinggi. Namun, hal ini terkendala oleh keterbatasan lahan kosong. Sehingga sering terjadi alih fungsi lahan. Alih fungsi lahan ini biasanya berdampak pada perubahan kerapatan vegetasi dan bangunan. Dimana perubahan tersebut disebabkan oleh lahan kosong atau vegetasi beralih fungsi menjadi lahan terbangun (Lumbantoruan, 2010).

\subsection{Normalized Difference Vegetation Index (NDVI)}

Normalized Difference Vegetation Index (NDVI) merupakan suatu perhitungan numerik sederhana yang berfungsi untuk menganalisis tingkat kehijauan suatu vegetasi yang diamati (Bhandari et al., 2012). NDVI biasanya digunakan untuk menganalisis kerapatan vegetasi, aborsi tanah oleh kanopi tumbuhan, kapasitas fotosintesis dll. Nilai indeks kerapatan vegetasi (NDVI) dalam pengaplikasiannya diperoleh melalui sebuah perhitungan antara Band NIR (Near Infrared) dengan Band Red yang terlihat oleh rekaman digital akibat pemantulan pigmen klorofil dari kanal merah (red) dan reflektansi maksimum di kanal sensitif infra merah (NIR) dari struktur selular daun pada tumbuhan (Purwanto, 2015). Penggunaan band/saluran NIR dan band/saluran RED dikarenakan band/saluran NIR yang memiliki sifat mendeteksi vegetasi dan juga dapat merefleksikan serta mentransmisikan radiasi matahari pada sel daun (Iswanto, 2008). Sehingga pengolahannya tumbuhan hijau hidup relatif tampil terang pada infrared dekat (NIR). Sedangkan band/saluran RED memiliki sifat untuk membedakan sudut vegetasi.

Algoritma NDVI dikembangkan oleh J.W. Rouse, R. H. Haas, J. A. Schell, \& D. W. pada tahun 1973 (Grover \& Singh, 2015), dengan rumus sebagai berikut:

$$
N D V I=\frac{N I R-R E D}{\mathrm{NIR}+\mathrm{RED}}
$$

\subsection{Normalized Difference Build-Up Index (NDBI)}

Normalized Difference Build-Up Index (NDBI) merupakan suatu metode algoritma yang berhasil di kembangkan oleh Zha Y., Gai J., \& Ni. S. Pada tahun 2003. NDBI merupakan suatu metode persamaan algoritma yang berfungsi untuk mencari atau menunjukkan indeks kerapatan lahan (Suwarsono \& Khomarudin, 2014). NDBI dalam pengaplikasiannya menggunakan karakteristik dari band/saluran SWIR dan NIR. Hal ini dikarenakan band/saluran NIR (near infra red) merupakan saluran yang sangat sensitif untuk mendeteksi vegetasi, sedangkan reflektasi untuk lahan terbuka dan lahan terbangun sangat rendah serta saluran ini juga mampu menunjukkan kandungan air dalam tanaman dan tanah. Sedangkan band/saluran SWIR (Short wavelength infra red) dapat mencerminkan kandungan kelembaban pada berbagai penggunaan tanah dan dapat berfungsi untuk membedakan tanaman tanah serta bangunan dengan baik. 
Model NDBI ini sangat bermanfaat untuk memonitoring serta perencanaan penggunaan lahan karena NDBI sangat sensitif terhadap lahan terbangun. Zha et al. (2003) mengembangkan perhitungan nilai NDBI dari data landsat TM dengan menggunakan persamaan sebagai berikut:

$$
N D B I=\frac{S W I R-N I R}{S W I R+N I R}
$$

\section{Hasil dan Pembahasan}

\subsection{Analisis Kerapatan Vegetasi}

Kerapatan vegetasi didapat melalui pengolahan algoritma NDVI menggunakan citra satelit landsat 5 TM (2005 dan 2011) dan citra satelit sentinel (2019). Berdasarkan hasil pengolahan dilakukan klasifikasi kerapatan vegetasi berdasarkan pada Tabel 1, sehingga didapatkan indeks kerapatan vegetasi Kota Banda Aceh seperti pada Gambar 3.

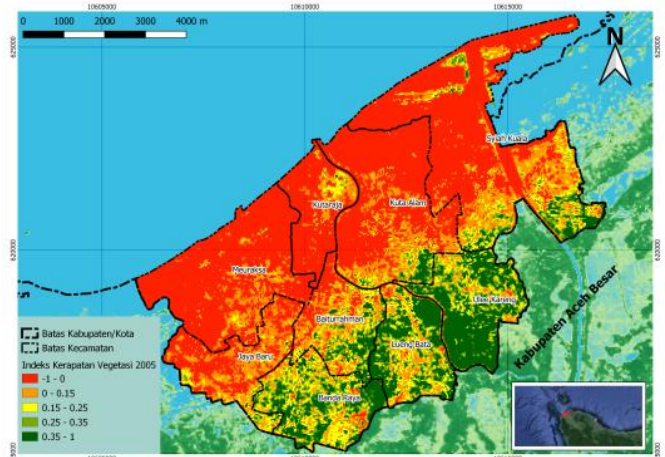

(2005)

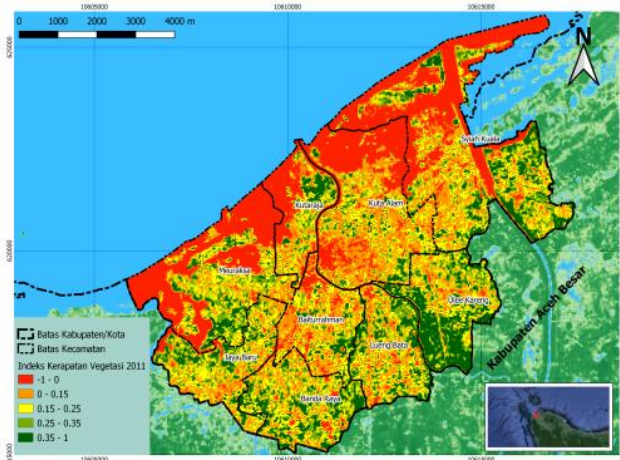

(2011)

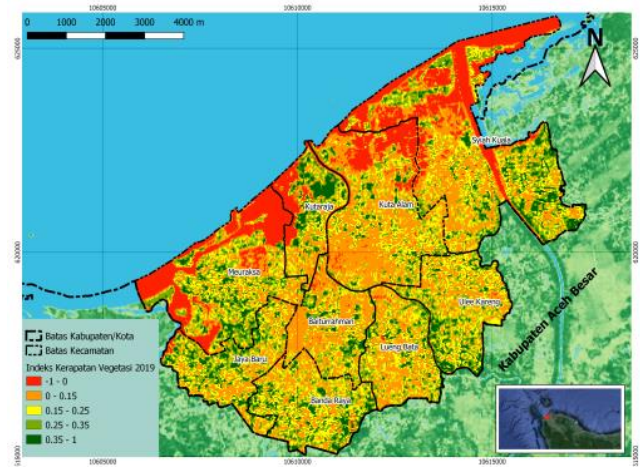

(2019)

Gambar 3. Kerapatan Vegetasi Kota Banda Aceh tahun 2005, 2011 dan 2019 (Analisis Penyusun, 2019)

Tabel 3. Luas Kerapatan Vegetasi Kota Banda Aceh (Analisis Penyusun, 2019)

\begin{tabular}{|c|c|c|c|c|c|c|c|c|c|c|}
\hline \multirow{3}{*}{$\begin{array}{c}\text { Kerapatan } \\
\text { Vegetasi }\end{array}$} & \multirow{2}{*}{\multicolumn{6}{|c|}{ Luas $(\mathrm{Ha})$}} & \multicolumn{4}{|c|}{ Perubahan Luas Kerapatan Vegetasi } \\
\hline & & & & & & & \multicolumn{2}{|c|}{$2005-2011$} & \multicolumn{2}{|c|}{ 2011-2019 } \\
\hline & 2005 & $\%$ & 2011 & $\%$ & 2019 & $\%$ & $\Delta$ & $\Delta \%$ & $\Delta$ & $\Delta \%$ \\
\hline Non Vegetasi & 2984.91 & 49.88 & $1,605.72$ & 26.83 & 960.57 & 16.06 & -1359.72 & -22.70 & -648.49 & -10.82 \\
\hline Jarang & 1207.07 & 20.17 & $1,533.67$ & 25.63 & $2,152.90$ & 35.99 & 296.10 & 4.94 & 603.80 & 10.08 \\
\hline Cukup Rapat & 567.58 & 9.49 & $1,215.39$ & 20.31 & 836.88 & 13.99 & 647.55 & 10.81 & -342.19 & -5.71 \\
\hline Rapat & 425.88 & 7.12 & 847.90 & 14.17 & $1,317.74$ & 22.03 & 424.71 & 7.09 & 447.23 & 7.46 \\
\hline Sangat Rapat & 798.34 & 13.34 & 781.89 & 13.07 & 714.68 & 11.95 & -8.64 & -0.14 & -60.34 & -1.01 \\
\hline
\end{tabular}

Hasil pengolahan dilakukan uji ketelitian dengan pengecekan data lapangan sebanyak 82 titik sampel yang dipilih berdasarkan persebaran kerapatan dan keraguan antara hasil pengolahan dengan kondisi lapangan. Tingkat akurasi yang di peroleh adalah sebesar $81,71 \%$. Berdasarkan analisis, dapat dilihat luas kerapatan vegetasi Kota Banda Aceh pada tahun 2005, 2011 dan 2019 (Tabel 3). Jika dilihat distribusi spasialnya, kerapatan vegetasi paling dominan 
terjadi pada kelas kerapatan jarang dan kelas kerapatan rapat yang terus mengalami pertambahan luas tiap tahunnya. Sementara itu, kelas kerapatan sangat rapat tiap tahunnya terus mengalami penurunan luas lahan.

Berdasarkan hasil analisis, diketahui terjadi peningkatan kerapatan vegetasi dari tahun 2005-2019. Perubahan kerapatan vegetasi paling dominan terjadi pada tahun 2005-2011, dengan kelas vegetasi cukup rapat mengalami pertambahan luas sebesar $10,81 \%$ dan kelas kerapatan vegetasi sangat rapat mengalami penurunan sebesar $-0,14 \%$. Sementara itu, perubahan kerapatan vegetasi yang terajadi pada tahun 2011-2019 juga mengalami penambahan luasan di beberapa kelas terutama pada kelas kerapatan vegetasi jarang yang mengalami pertambahan luas sebesar $10,08 \%$. Disisi lain, terdapat beberapa kelas yang mengalami penurunan luas seperti kelas kerapatan rapat (-1.01\%) dan kelas kerapatan cukup rapat (5.71\%).

Hasil dari indeks kerapatan vegetasi (Gambar 3 dan Tabel 3), selanjutnya diolah kembali untuk mengetahui besar transisi perubahan antara kelas kerapatan satu terhadap kelas kerapatan vegetasi lainnya dengan menggunakan bantuan plugin Molusce: Change Area yang berada pada software QGIS 3.18. Transisi perubahan kerapatan vegetasi yang terjadi pada tahun 2005-2011 dan 2011-2019 dapat dilihat pada Tabel 4 dan Tabel 5.

Tabel 4. Matriks Transisi perubahan kerapatan vegetasi tahun 2005-2011 (Analisis Penyusun, 2019)

\begin{tabular}{|c|c|c|c|c|c|c|c|c|c|c|c|c|}
\hline & \multicolumn{11}{|c|}{2011} & \multirow{3}{*}{ TOTAL } \\
\hline \multirow{7}{*}{ ํํㅇ } & & \multicolumn{2}{|c|}{ Non Vegetasi } & \multicolumn{2}{|c|}{ Jarang } & \multicolumn{2}{|c|}{ Cukup Rapat } & \multicolumn{2}{|c|}{ Rapat } & \multicolumn{2}{|c|}{ Sangat Rapat } & \\
\hline & & $\mathrm{Ha}$ & $\%$ & $\mathrm{Ha}$ & $\%$ & $\mathrm{Ha}$ & $\%$ & $\mathrm{Ha}$ & $\%$ & $\mathrm{Ha}$ & $\%$ & \\
\hline & Jarang & 62.91 & 5.20 & 456.57 & 37.71 & 320.49 & 26.47 & 211.68 & 17.49 & 158.94 & 13.13 & 1210.59 \\
\hline & $\begin{array}{l}\text { Cukup } \\
\text { Rapat }\end{array}$ & 14.40 & 2.47 & 174.06 & 29.91 & 210.42 & 36.15 & 106.83 & 18.35 & 76.32 & 13.11 & 582.03 \\
\hline & Rapat & 5.40 & 1.22 & 75.15 & 16.99 & 166.86 & 37.71 & 130.23 & 29.43 & 64.80 & 14.65 & 442.44 \\
\hline & $\begin{array}{c}\text { Sangat } \\
\text { Rapat }\end{array}$ & 5.04 & 0.64 & 49.14 & 6.26 & 121.41 & 15.46 & 211.68 & 26.96 & 397.89 & 50.68 & 785.16 \\
\hline & TOTAL & \multicolumn{2}{|c|}{1608.57} & \multicolumn{2}{|c|}{1506.69} & \multicolumn{2}{|c|}{1229.58} & \multicolumn{2}{|c|}{867.15} & \multicolumn{2}{|c|}{776.52} & 5988.51 \\
\hline
\end{tabular}

Berdasarkan matriks transisi tahun 2005-2011, dapat diketahui perubahan kerapatan vegetasi paling dominan terjadi pada kelas vegetasi jarang terhadap vegetasi cukup rapat sebesar $320.49 \mathrm{Ha}$ atau $26.47 \%$ dari total luas kerapatan vegetasi jarang pada tahun 2005. Perubahan kerapatan vegetasi yang dominan lainnya terjadi pada kelas kerapatan sangat rapat yang terkonversi menjadi kerapatan rapat sebesar 211.68 ha atau $26,96 \%$ dari luas total kerapatan vegetasi sangat rapat pada tahun 2005 .

Tabel 5. Matriks Transisi perubahan kerapatan vegetasi tahun 2011-2019 (Analisis Penyusun, 2019)

\begin{tabular}{|c|c|c|c|c|c|c|c|c|c|c|c|c|}
\hline & \multicolumn{11}{|c|}{2011} & \multirow{3}{*}{ TOTAL } \\
\hline \multirow{6}{*}{ 옹 } & & \multicolumn{2}{|c|}{ Non Vegetasi } & \multicolumn{2}{|c|}{ Jarang } & \multicolumn{2}{|c|}{ Cukup Rapat } & \multicolumn{2}{|c|}{ Rapat } & \multicolumn{2}{|c|}{ Sangat Rapat } & \\
\hline & & $\mathrm{Ha}$ & $\%$ & $\mathrm{Ha}$ & $\%$ & $\mathrm{Ha}$ & $\%$ & $\mathrm{Ha}$ & $\%$ & $\mathrm{Ha}$ & $\%$ & \\
\hline & Jarang & 23.56 & 1.56 & 1005.16 & 66.74 & 249.38 & 16.56 & 181.75 & 12.07 & 46.22 & 3.07 & 1506.08 \\
\hline & $\begin{array}{l}\text { Cukup } \\
\text { Rapat }\end{array}$ & 3.96 & 0.32 & 393.99 & 32.05 & 341.92 & 27.81 & 394.44 & 32.08 & 95.15 & 7.74 & 1229.45 \\
\hline & Rapat & 0.81 & 0.09 & 127.16 & 14.64 & 175.18 & 20.16 & 399.56 & 45.99 & 166.10 & 19.12 & 868.82 \\
\hline & $\begin{array}{c}\text { Sangat } \\
\text { Rapat }\end{array}$ & 0.63 & 0.08 & 49.10 & 6.30 & 69.43 & 8.91 & 279.59 & 35.90 & 380.05 & 48.80 & 778.80 \\
\hline & OTAL & \multicolumn{2}{|c|}{961.10} & \multicolumn{2}{|c|}{2109.88} & \multicolumn{2}{|c|}{887.26} & \multicolumn{2}{|c|}{1316.05} & \multicolumn{2}{|c|}{718.46} & 5992.74 \\
\hline
\end{tabular}

Berdasarkan matriks transisi kerapatan vegetasi tahun 2011-2019 pada Tabel 7, menunjukkan perubahan paling dominan terjadi pada kelas kerapatan cukup rapat yang terkonversi menjadi kelas kerapatan vegetasi rapat sebesar 394.44 Ha atau sekitar 32.08\% dari luas total kelas kerapatan vegetasi rapat pada tahun 2011. Kerapatan vegetasi yang mengalami perubahan paling dominan lainnya terjadi pada kelas kerapatan sangat rapat yang terkonversi menjadi $279.59 \mathrm{Ha}$ atau sekitar $35.90 \%$ dari luas total kelas kerapatan sangat rapat pada tahun 2011. Disisi lain, kelas kerapatan yang mengalami perubahan paling sedikit terjadi pada kelas 
kerapatan sangat rapat yang terkonversi menjadi non vegetasi yaitu sebesar 0,63 Ha atau sekitar 0,08\% dari luas total kelas kerapatan sangat rapat pada tahun 2011.

Secara keseluruhan, jika dilihat pada Gambar 3 perubahan kerapatan vegetasi yang terjadi pada tahun 2005-2011 lebih mulai tersebar merata di seluruh wilayah Kota Banda Aceh. Pada tahun 2005, persebaran kerapatan vegetasi lebih dominan terjadi pada bagian selatan Kota Banda Aceh, hal ini dikarenakan dampak dari bencana tsunami. Sementara itu, pada tahun 2011 persebaran kerapatan vegetasi sudah mulai tersebar merata di seluruh kecamatan di Kota Banda Aceh. Sedangkan pada tahun 2011-2019, peningkatan perubahan kerapatan vegetasi lebih dominan terjadi di bagian utara Kota Banda Aceh atau di sekitar daerah pesisir dan cenderung mengalami penurunan di bagian selatan Kota Banda Aceh.

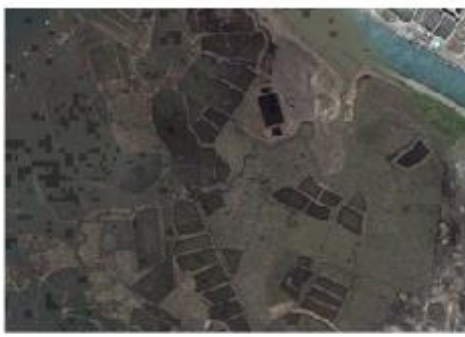

(A)

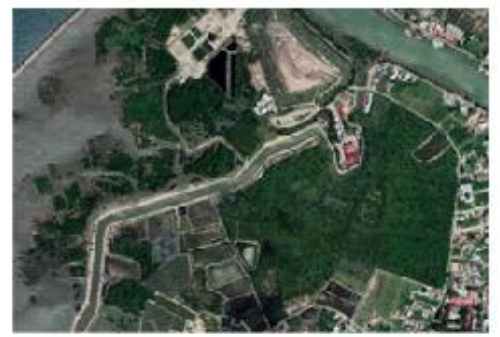

(B)

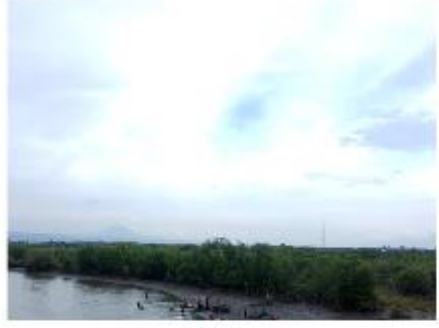

(C)

Gambar A. Kondisi lahan Hutan Mangrove Banda Aceh tahun 2005

Gambar B. Kondisi lahan Hutan Mangrove Banda Aceh tahun 2019

Gambar C. Foto Eksisting Hutan Mangrove Banda Aceh

Gambar 4. Persebaran vegetasi di bagian utara Kota Banda ACeh (Analisis Penyusun, 2019)

Persebaran vegetasi di bagian utara lebih pada penanaman vegetasi mangrove yang difungsikan sebagai mitigasi bencana untuk pemecah ombak besar atau tsunami. Sedangkan penurunan kerapatan vegetasi yang terjadi di bagian selatan Kota Banda Aceh disebabkan oleh pesatnya pembangunan lahan terbangun.

\subsection{Analisis Kerapatan Bangunan}

Kerapatan bangunan Kota Banda Aceh didapat dari hasil pengolahan citra landsat 5 TM (2005 dan 2011) dan citra satelit sentinel-2 (2019) dengan menggunakan algoritma NDBI. Hasil dari indeks kerapatan bangunan dapat dilihat pada Gambar 5 yang didapat dari hasil klasifikasi kerapatan bangunan pada Tabel 2 .

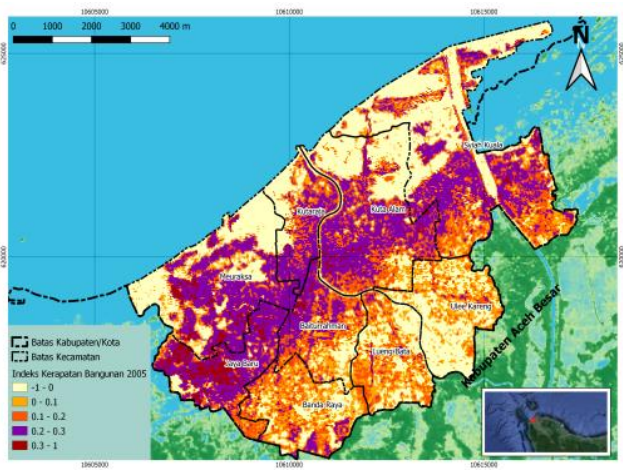

(2005)

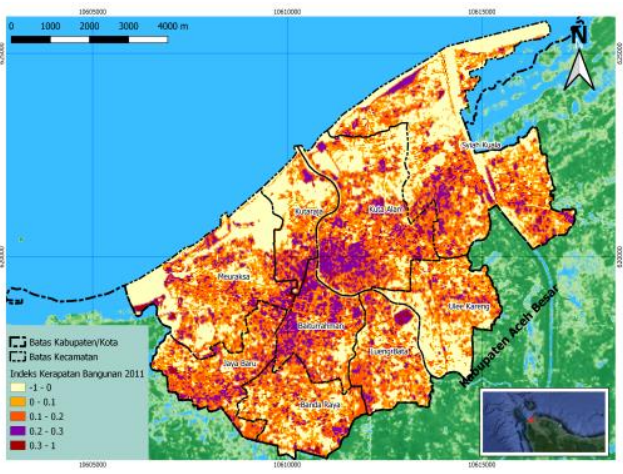

(2011) 


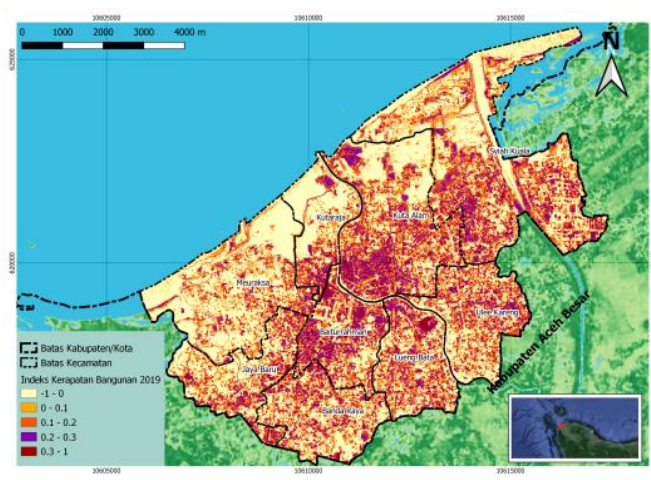

(2019)

Gambar 5. Kerapatan Bangunan Kota Banda Aceh tahun 2005, 2011 dan 2019 (Analisis Penyusun, 2019)

Tabel 6. Luas Kerapatan Bangunan Kota Banda Aceh (Analisis Penyusun, 2019)

\begin{tabular}{|c|c|c|c|c|c|c|c|c|c|c|}
\hline \multirow{3}{*}{$\begin{array}{l}\text { Kerapatan } \\
\text { Bangunan }\end{array}$} & \multirow{2}{*}{\multicolumn{6}{|c|}{ Luas (Ha) }} & \multicolumn{4}{|c|}{ Perubahan Luas Kerapatan Bangunan } \\
\hline & & & & & & & \multicolumn{2}{|c|}{$2005-2011$} & \multicolumn{2}{|c|}{ 2011-2019 } \\
\hline & 2005 & $\%$ & 2011 & $\%$ & 2019 & $\%$ & $\Delta$ & $\Delta \%$ & $\Delta$ & $\Delta \%$ \\
\hline Non Terbangun & 1972.83 & 33.02 & 1915.46 & 32.06 & 2778.59 & 46.38 & -57.92 & -0.97 & 860.94 & 14.38 \\
\hline Rendah & 941.45 & 15.76 & 1512.15 & 25.31 & 615.62 & 10.28 & 571.06 & 9.53 & -891.64 & -14.89 \\
\hline Sedang & 1243.64 & 20.82 & 1738.67 & 29.10 & 1467.92 & 24.50 & 495.70 & 8.27 & -289.20 & -4.83 \\
\hline Tinggi & 1602.72 & 26.83 & 735.06 & 12.30 & 894.22 & 14.93 & -868.19 & -14.49 & 151.71 & 2.53 \\
\hline Sangat Tinggi & 213.64 & 3.58 & 72.95 & 1.22 & 233.95 & 3.91 & -140.65 & -2.35 & 168.19 & 2.81 \\
\hline
\end{tabular}

Uji akurasi yang didapatkan dari hasil indeks kerapatan bangunan yaitu sebesar 84,1\% yang artinya hasil pengolahan dapat digunakan. Berdasarkan hasil analisis, diketahui bahwa kelas kerapatan bangunan yang paling dominan terjadi pada kelas kerapatan sedang. Sedangkan kelas kerapatan yang mengalami penurunan luas terjadi pada kelas sangat tinggi. Sementara itu, jika dilihat berdasarkan perubahannya, Kota Banda Aceh mengalami perubahan kerapatan bangunan paling besar terjadi pada tahun 2005-2011. Perubahan paling dominan terjadi pada kelas kerapatan rendah yang mengalami pertambahan luasan sebesar 9,53\%. Sedangkan pada tahun 2011-2019, kerapatan bangunan terus mengalami pertambahan luasan. Perubahan paling dominan terjadi pada kelas kerapatan sangat tinggi yang mengalami pertambahan luas sebesar $2.81 \%$ dan kelas kerapatan tinggi yang mengalami pertambahan luasan $2.53 \%$. Disisi lain, kelas kerapatan rendah mengalami penurunan yang cukup besar yaitu mencapai $-14.89 \%$. berdasarkan hasil klasifikasi kerapatan pada Gambar 5 dan Tabel 6 dapat dilihat besar transisi perubahan antara kelas kerapatan satu terhadap kelas kerapatan bangunan lainnya seperti yang ditunjukkan pada Tabel 7 dan Tabel 8.

Tabel 7. Matriks Transisi perubahan kerapatan bangunan tahun 2005-2011 (Analisis Penyusun, 2019)

\begin{tabular}{|c|c|c|c|c|c|c|c|c|c|c|c|c|}
\hline & \multicolumn{11}{|c|}{2011} & \multirow{3}{*}{ TOTAL } \\
\hline \multirow{6}{*}{ 윰 } & & \multicolumn{2}{|c|}{ Non Terbangun } & \multicolumn{2}{|c|}{ Jarang } & \multicolumn{2}{|c|}{ Sedang } & \multicolumn{2}{|c|}{ Tinggi } & \multicolumn{2}{|c|}{ Sangat Tinggi } & \\
\hline & & $\mathrm{Ha}$ & $\%$ & $\mathrm{Ha}$ & $\%$ & $\mathrm{Ha}$ & $\%$ & $\mathrm{Ha}$ & $\%$ & $\mathrm{Ha}$ & $\%$ & \\
\hline & $\begin{array}{c}\text { Non } \\
\text { Terbangun }\end{array}$ & 1307.15 & 65.92 & 382.48 & 19.29 & 212.96 & 10.74 & 69.43 & 3.50 & 10.97 & 0.55 & 1982.98 \\
\hline & Jarang & 226.90 & 24.00 & 363.95 & 38.50 & 294.26 & 31.12 & 55.13 & 5.83 & 5.22 & 0.55 & 945.45 \\
\hline & Sedang & 183.46 & 14.72 & 343.09 & 27.52 & 544.44 & 43.68 & 163.31 & 13.10 & 12.23 & 0.98 & 1246.53 \\
\hline & $\begin{array}{l}\text { Sangat } \\
\text { Tinggi }\end{array}$ & 33.10 & 15.48 & 56.66 & 26.50 & 66.01 & 30.88 & 49.73 & 23.26 & 8.27 & 3.87 & 213.77 \\
\hline & TOTAL & \multicolumn{2}{|c|}{1925.07} & \multicolumn{2}{|c|}{1516.51} & \multicolumn{2}{|c|}{1742.24} & \multicolumn{2}{|c|}{736.17} & \multicolumn{2}{|c|}{73.11} & 5993.10 \\
\hline
\end{tabular}

Berdasarkan matriks transisi perubahan yang ditunjukkan pada Tabel 7, perubahan paling besar pada tahun 2005-2011 terjadi pada kelas kerapatan tinggi yang terkonversi menjadi kelas kerapatan sedang sebesar 624.57 Ha atau mencapai 38.93\% dari luas total kelas kerapatan bangunan tinggi pada tahun 2005. Kelas kerapatan yang mengalami perubahan paling besar juga 
terjadi pada kelas kerapatan sedang yang terkonversi menjadi kelas kerapatan jarang sebesar 343.09 Ha atau mencapai 27,52\% dari luas total kerapatan bangunan sedang pada tahun 2005 .

Tabel 8. Matriks Transisi perubahan kerapatan bangunan tahun 2011-2019 (Analisis Penyusun, 2019)

\begin{tabular}{|c|c|c|c|c|c|c|c|c|c|c|c|c|}
\hline & \multicolumn{11}{|c|}{2019} & \multirow{3}{*}{ TOTAL } \\
\hline \multirow{7}{*}{ 궁 } & & \multicolumn{2}{|c|}{ Non Terbangun } & \multicolumn{2}{|c|}{ Jarang } & \multicolumn{2}{|c|}{ Sedang } & \multicolumn{2}{|c|}{ Tinggi } & \multicolumn{2}{|c|}{ Sangat Tinggi } & \\
\hline & & $\mathrm{Ha}$ & $\%$ & $\mathrm{Ha}$ & $\%$ & $\mathrm{Ha}$ & $\%$ & $\mathrm{Ha}$ & $\%$ & $\mathrm{Ha}$ & $\%$ & \\
\hline & $\begin{array}{c}\text { Non } \\
\text { Terbangun }\end{array}$ & 1358.22 & 70.76 & 169.63 & 8.84 & 249.31 & 12.99 & 114.98 & 5.99 & 27.46 & 1.43 & 1919.60 \\
\hline & Jarang & 750.55 & 49.53 & 192.41 & 12.70 & 373.48 & 24.65 & 167.02 & 11.02 & 31.87 & 2.10 & 1515.33 \\
\hline & Sedang & 548.06 & 31.46 & 202.14 & 11.60 & 574.62 & 32.99 & 342.14 & 19.64 & 75.09 & 4.31 & 1742.05 \\
\hline & $\begin{array}{l}\text { Sangat } \\
\text { Tinggi }\end{array}$ & 9.90 & 13.55 & 3.15 & 4.31 & 15.04 & 20.57 & 23.59 & 32.27 & 21.43 & 29.31 & 73.11 \\
\hline & TOTAL & \multicolumn{2}{|c|}{2780.54} & \multicolumn{2}{|c|}{623.69} & \multicolumn{2}{|c|}{1452.85} & \multicolumn{2}{|c|}{888.22} & \multicolumn{2}{|c|}{241.30} & 5986.60 \\
\hline
\end{tabular}

Pada Tabel 8 menunjukkan matriks transisi perubahan kerapatan bangunan tahun 20112019. Perubahan paling dominan terjadi pada kelas kerapatan jarang yang terkonversi menjadi kelas kerapatan sedang yaitu sebesar 373.48 atau mencapai $25.65 \%$ dari luas total kelas kerapatan bangunan jarang pada tahun 2011. Perubahan paling dominan lainnya terjadi pada kelas kerapatan sedang yang terkonversi menjadi kelas kerapatan tinggi yaitu mencapai $342.14 \%$ atau sekitar $19.64 \%$ dari luas total kelas kerapatan bangunan tinggi pada tahun 2001 .

Secara keseluruhan, perubahan kerapan bangunan paling besar terjadi pada periode 20052011. Pada tahun 2005, persebaran kerapatan bangunan hanya tersebar di pusat kota, bagian timur, barat dan selatan Kota Banda Aceh. Sementara itu, pada bagian utara atau daerah pesisir pantai lebih pada persebaran lahan kosong yang disebabkan oleh bencana tsunami. Sedangkan pada tahun 2011, perkembangan kerapatan bangunan mulai tersebar merata diseluruh kecamatan Kota Banda Aceh terutama di bagian selatan Kota Banda Aceh. Sementara itu, pada tahun 2011-2019, luas kerapatan bangunan terus mengalami pertambahan meskipun tidak sebesar periode sebelumnya. Perubahan lahan bangunan pada periode saat ini lebih cenderung terjadi di bagian timur dan selatan kota Banda Aceh.

Secara umum, perubahan kerapatan vegetasi dan bangunan saling berkaitan, seperti yang terjadi di bagian selatan dan timur Kota Banda Aceh dimana kerapatan bangunan semakin tinggi dan diikuti dengan kerapatan vegetasi yang menjadi semakin rendah. Perubahan yang terjadi pada kerapatan vegetasi dan bangunan ini didukung oleh beberapa sebab seperti adanya implementasi kebijakan pemerintah terkait perencanaan pusat kota baru yang tersusun dalam RTRW Kota Banda Aceh yang terletak di bagian selatan Kota Banda Aceh tepatnya berada di Kecamatan Lueng Bata. Perubahan kerapatan ini juga didukung juga oleh Peraturan Menteri PU tentang pedoman perencanaan umum pengembangan infrastruktur di kawasan rawan tsunami tahun 2009 yang menjelaskan bahwa pembangunan kota pasca bencana tsunami harus menghindari pembangunan di zona rawan kerusakan tinggi.

Perubahan kerapatan vegetasi dan bagunan yang terjadi di bagian timur dan selatan Kota Banda Aceh tepatnya berada di Kecamatan Syiah Kuala, Kecamatan Ulee Kareng dan Kecamatan Kuta Alam disebabkan oleh beberapa faktor diantaranya karakteristik fisik alam dan buatan seperti tingkat kelerengan rata-rata cenderung datar dan didukung oleh adanya faktor penarik berupa tingkat aksesibilitas yang tergolong tinggi. Selain itu, perubahan kerapatan vegetasi dan bangunan juga terjadi dikarenakan tingginya intesitas pertumbuhan penduduk yang terjadi di Kota Banda Aceh yang menyebabkan kebutuhan akan lahan terus meningkat. Pertumbuhan penduduk ini didukung oleh adanya kawasan pendidikan yaitu Universitas Syiah Kuala dan UIN Ar-Raniry serta cepatnya pertumbuhan sektor ekonomi di daerah tersebut.

\section{Kesimpulan}

Perubahan kerapatan vegetasi Kota Banda Aceh pada tahun 2005-2011 paling tinggi terjadi pada kelas kerapatan cukup rapat sebesar 647,55 Ha atau mencapai 10,81\% dan kelas kerapatan sangat rapat mengalami penurunan sebesar 8,64 Ha atau mencapai $-0,14 \%$. Sementara itu pada tahun 2011-2019, perubahan kerapatan vegetasi paling tinggi terjadi pada kelas kerapatan jarang sebesar 603,80 $\mathrm{Ha}$ atau mencapai $10,08 \%$ dan kelas kerapatan cukup rapat 
mengalami penurunan luas sebesar 342.19 Ha tau mencapai 5,71\%. Kerapatan vegetasi tinggi sebagian besar berada di Kota Banda Aceh bagian utara yang difungsikan sebagai hutan mangrove untuk mitigasi bencana. Disisi lain, Perubahan kerapatan bangunan Kota Banda Aceh pada tahun 2005-2011 paling tinggi terjadi pada kelas kerapatan rendah sebesar 571,06 Ha atau mencapai $9,53 \%$ dan kelas kerapatan bangunan yang mengalami penurunan terjadi pada kelas kerapatan tinggi sebesar 868,19 Ha atau mencapai 14,49\%. Sedangkan pada tahun 2011-2019, perubahan kerapatan bangunan yang mengalami peningkatan paling luas terjadi pada kelas kerapatan sangat tinggi sebesar 168,19 Ha atau mencapai $2.81 \%$ dan kelas kerapatan yang mengamai penurunan luas paling tinggi terjadi pada kelas kerapatan rendah sebesar 891,64 Ha atau mencapai $14,89 \%$. Dibagian selatan Kota Banda Aceh, secara umum didapatkan bahwa daerah yang kerapatan bangunan semakin tinggi maka diikuti dengan kerapatan vegetasi yang semakin rendah.

\section{Referensi}

Aftriana, C. V. (2013). Analisis Perubahan Kerapatan Vegetasi Kota Semarang Menggunakan Bantuan Teknologi Penginderaan Jauh. Universitas Negeri Semarang.

Anderson, J. R., Hardy, E. E., Roach, J. T., \& Witmer, R. E. (1976). A Land Use And Land Cover Classification System For Use With Remote Sensor Data. Development, 2001(964), 41. https://doi.org/10.1016/j.jpsychores.2005.02.009

Bhandari, A. K., Kumar, A., \& Singh, G. K. (2012). Feature Extraction using Normalized Difference Vegetation Index ( NDVI ): a Case Study of Jabalpur City. 6, 612-621. https://doi.org/10.1016/j.protcy.2012.10.074

Choudhary, K., Boori, M. S., \& Kupriyanov, A. (2018). Spatial modelling for natural and environmental vulnerability through remote sensing and GIS in Astrakhan, Russia. Egyptian Journal of Remote Sensing and Space Science, 2l(2), 139-147. https://doi.org/10.1016/j.ejrs.2017.05.003

Congalton, R. G. (1991). A Review of Assessing the Accuracy of Classifications of Remotely Sensed Data. 46(October 1990), 35-46.

Gascon, M., Cirach, M., Martínez, D., \& Dadvand, P. (2016). Urban Forestry \& Urban Greening Normalized difference vegetation index ( NDVI ) as a marker of surrounding greenness in epidemiological studies : The case of Barcelona city. Urban Forestry \& Urban Greening, 19, 8894. https://doi.org/10.1016/j.ufug.2016.07.001

Grover, A., \& Singh, R. B. (2015). Analysis of Urban Heat Island (UHI) in Relation to Normalized Difference Vegetation Index (NDVI): A Comparative Study of Delhi and Mumbai. 125-138. https://doi.org/10.3390/environments2020125

Hardyanti, L., Wibowo, A., Kunci, K., \& Daratan, S. P. (2017). Variasi Spasial Temporal Suhu Permukaan Daratan Di Kota Jakarta Tahun 2015 dan 2016. Industrial Research Wiorkshop and National Seminar Politeknik Negeri Bandung, 704-713.

Hendarto, R. M. (1997). Teori Perkembangan dan Pertumbuhan Kota. Makalah Diskusi Rutin Fakultas Ekonomi.

Iswanto, P. A. (2008). Urban Heat Island di Kota Pangkalpinang tahun 2000 dan 2006. Universitas Indonesia.

Jia, K., Liang, S., Wei, X., Yao, Y., Su, Y., Jiang, B., \& Wang, X. (2014). Land Cover Classification of Landsat Data with Phenological Features Extracted from Time Series MODIS NDVI Data. (Mlc), 11518-11532. https://doi.org/10.3390/rs61111518

Kurniawati, F. E. (2010). Perkembangan Struktur Ruang Kota Semarang Periode 1960-2007. Skripsi. Universitas Muhammadiyah Surakarta.

Lumbantoruan, W. (2010). Studi Perkembangan Kota Medan Menggunakan Data Penginderaan Jauh dan SIG. Geografi, 2(2), 93-106.

Purwanto, A. (2015). Pemanfaatan Citra Landsat 8 untuk Identifikasi Normalized Difference Vegetation Index ( NDVI ) di Kecamatan Silat Hilir Kabupaten Kapuas Hulu. Jurnal Edikasi, 13, 27-36.

Sujarto Djoko, 1990. Faktor Sejarah Perkembangan Kota Di Dalam Perencanaan Pembangunan Kota. Tidak Dipublikasikan. Departemen Planologi, Fakultas Teknik Sipil dan Perencanaan. Institut Teknologi Bandung, Bandung.

Suwarsono, S., \& Khomarudin, R. (2014). Deteksi Wilayah Permukiman Pada Bentuk Lahan Vilkanin Menggunakan Citra Landsat - 8 OLI Berdasarkan Parameter Normalized Difference Build-pP Index ( NDBI ). (April). https://doi.org/10.13140/2.1.5112.9603.

Zha, Y., Gao, J., \& Ni, S. (2003). Use of normalized difference built-up index in automatically mapping urban areas from TM imagery. International Journal of Remote Sensing, 24(3), 583-594. 